\title{
MAPPING GROUNDWATER VULNERABILITY IN SCOTLAND: A NEW APPROACH FOR THE WATER FRAMEWORK DIRECTIVE
}

\author{
B E Ó Dochartaigh ${ }^{1}$, D F Ball ${ }^{1}$, A M MacDonald ${ }^{1}$, A Lilly ${ }^{2}$, V Fitzsimons ${ }^{3}$, M del Rio ${ }^{1}$ and \\ C A Auton ${ }^{1}$ \\ ${ }^{1}$ British Geological Survey, West Mains Road, Edinburgh EH9 3LA \\ ${ }^{2}$ Macaulay Land Use Research Institute, Craigiebuckler, Aberdeen AB15 8QH \\ ${ }^{3}$ Scottish Environment Protection Agency, Heriot Watt Research Park, Edinburgh EH14 4AP
}

Synopsis: A new methodology for groundwater vulnerability assessment has been devised for Scotland to meet the requirements of the Water Framework Directive. Using the methodology, a new GIS-based map of groundwater vulnerability has been produced, at a working scale of 1:100 000. The map is being used by the Scottish Environment Protection Agency (SEPA) to help characterise and assess risk to groundwater bodies.

The methodology assesses the vulnerability of groundwater in the uppermost aquifer to the vertical downward movement of a non-specific contaminant from the ground surface. It considers the intrinsic properties of the pathway between the ground surface and the water table. The key difference from previous vulnerability maps in Scotland and the rest of the UK is that the new method assesses vulnerability in all aquifers regardless of resource potential. This reflects the diverse environmental objectives for groundwater bodies under the Water Framework Directive. This approach provides the flexibility to combine the groundwater vulnerability map with maps of pressures, groundwater resources or other groundwater-related receptors, as required.

\section{Introduction}

Groundwater in Scotland is a valuable resource. It provides private water supplies to many thousands of properties and farms, and is also a source for public water supply. Many terrestrial ecosystems are fed by groundwater from springs and by seepage. During the summer months, groundwater helps to maintain river flows via baseflow discharge. In much of Scotland, the natural groundwater quality is good. However, deterioration in the quality of groundwater can occur, usually associated with human activity. One cause of deterioration is saline intrusion, generally caused by over abstraction, but the main concern in Scotland is the leaching of chemicals (derived from agricultural practices or the disposal of domestic and industrial wastes) vertically down into the ground.

Assessing the degree to which natural groundwater quality is affected by human activities is one of the objectives of the EU Water Framework Directive 2000/60/EC. The Water Framework Directive is one of the most significant pieces of European water legislation to be produced in recent years. It expands the scope of protection to all waters (surface, subsurface and coastal), with the aim of meeting specified environmental objectives by 2015. In order to achieve the objectives set out in Article 4 of the Water Framework Directive, and in order to manage surface and groundwater in an integrated way, the Directive introduces River Basin Districts and requires that a River Basin Management Plan (RBMP) be produced for each district. The initial phase of the RBMP involves delineation and characterisation of water 
bodies (surface, groundwater and coastal) within each district, and assessments of their uses and the degree to which they are at risk of failing to meet the relevant environmental objectives. The Directive specifies that any geological formation that is capable of providing a groundwater supply of at least $10 \mathrm{~m}^{3} \mathrm{~d}^{-1}$ is considered to be an aquifer and must consequently be designated as a groundwater body. This is a lower threshold than has previously been used in the UK to designate aquifers for the basis of groundwater protection, and means that all bedrock formations in Scotland will be designated as groundwater bodies.

The risk assessment component of groundwater body characterisation involves both an assessment of the likelihood that certain pressures will adversely affect the underlying groundwater body or downstream receptors (such as abstraction boreholes and groundwaterdependent ecosystems) to the extent that the groundwater body will fail to achieve good chemical status by 2015. The body responsible for the protection of the environment and the implementation of the Water Framework Directive in Scotland is the Scottish Environment Protection Agency (SEPA). SEPA's strategy for the implementation of the groundwater protection aspects of the Water Framework Directive requires an assessment of the susceptibility of groundwater bodies, and associated receptors, to contamination, for the whole of Scotland.

An integral part of the strategy is to provide a regional scale, relative assessment of:

the vertical pathway by which contaminants can reach groundwater within a groundwater body, and, in certain situations,

the lateral pathway by which contaminants within the groundwater body can migrate to downgradient receptors.

Using simple, regional scale screening principles, the lateral pathway is being assessed using maps of aquifer productivity for bedrock and superficial deposits, which have been produced by the British Geological Survey (BGS) (MacDonald et al. 2005). The vertical pathway assessment is based on the new assessment of groundwater vulnerability described in this paper.

Previous groundwater vulnerability assessments in Scotland were not adequate for the Water Framework Directive as they were either at too small a scale, or were not available for all groundwater bodies. SEPA also required that the groundwater vulnerability map be GIS-based, to form part of their suite of GIS-based national maps.

The new methodology and map are intended to assess the vulnerability of groundwater in the uppermost aquifer to a potential contaminant moving through the vertical pathway from the land surface. In aquifers with low groundwater resource potential, such as is the case for most Lower Palaeozoic and Precambrian basement rocks, the capacity for dilution, dispersion or other attenuation of contaminants is very low. A small loading of contaminant may therefore have a major negative impact on groundwater quality and on the chemical status of associated surface ecosystems.

There are differences between the new methodology and that of previous aquifer vulnerability assessments, such as the nitrate vulnerable zone assessment for Scotland (Ball et al. 2005) or the Environment Agency/BGS 1:100 000 scale maps of England and Wales (Palmer and Lewis 1998, Robins et al. 2004). A key difference is that the new methodology does not specifically take account of the value of the uppermost aquifer as a drinking water supply, but reflects the more diverse environmental objectives for groundwater bodies under the Water Framework 
Directive. This provides the flexibility to combine the groundwater vulnerability map with maps of pressures, aquifer resources, or groundwater receptors, as appropriate.

The new groundwater vulnerablity map is not therefore intended to be a complete solution to groundwater risk assessment. Instead, it is designed to be one of a suite of maps to link pressures with vertical groundwater pathways and downstream lateral pathways to different receptors, such as large groundwater abstractions or surface water ecosystems. It is therefore a vital component in SEPA's groundwater characterisation methodology and has the potential to play a key role in integrated water management strategies.

Work on the new groundwater vulnerability methodology and map was carried out by BGS and the Macaulay Land Use Research Institute (MLURI) through a project administered by the Scotland and Northern Ireland Forum for Environmental Research (SNIFFER) on behalf of SEPA and the Environment and Heritage Service, Northern Ireland (E\&HS). A steering group was drawn from relevant agencies in Scotland, England and Wales, Northern Ireland and the Republic of Ireland. Many of the principles of the methodology are based on those adopted in the Republic of Ireland (DELG/EPA/GSI, 1999).

\section{Basic concepts of groundwater vulnerability used in the new methodology}

Groundwater vulnerability is a term that has been in use for more than 30 years and has been interpreted in different ways. The accepted definition of groundwater vulnerability in the UK and most other European countries, amended slightly to reflect the principles outlined above, is 'the tendency and likelihood for general contaminants to reach the water table within the uppermost aquifer after introduction at the ground surface'. All groundwater is to some extent vulnerable to contamination from surface or sub-surface sources (Foster 1998), and one of the objectives of vulnerablity maps is to integrate geological and hydraulic characteristics of aquifers and overlying material to indicate the relative risk to groundwater from contamination.

For the new Water Framework Directive screening methodology, groundwater vulnerability is defined in the context of the standard hazard-pathway-receptor model:

Hazard: land use activities that pose a threat to groundwater, including waste disposal, urban development, farming, and mining. The new methodology considers a non-specific contaminant that is conservative in its behaviour in groundwater, and assumes that all hazards are released at ground level. It is also possible to consider less conservative and deeper releases of contaminants at a screening level using the same methodology, by applying the datasets underpinning the vulnerability map in different ways.

Pathway: all material between the hazard and the receptor. This will comprise any superficial materials overlying the uppermost aquifer and, in certain circumstances, the unsaturated zone within the aquifer itself.

Receptor: the aspect of groundwater that is at risk. In the new methodology, this is groundwater in the uppermost aquifer vertically below the hazard. Other downstream receptors, such as abstraction boreholes and groundwater-dependent surface ecosystems, can be assessed at a screening level by combining the vulnerability map with other tools such as aquifer productivity maps.

The characteristics of the pathway that influence groundwater vulnerability within the new methodology are those controlling the rate of vertical movement of infiltrating water and the degree of attenuation of contaminants. 
The travel time of contaminants in the pathway not only directly affects the timing of their arrival at the water table, but also has a bearing on the degree of attenuation that can occur. For example, microbial contaminants degrade over time, and the longer they remain in the pathway the smaller is their impact. At a regional scale screening level, travel time is assumed to be controlled by the pathway thickness and by the permeability and groundwater flow type of the component geological material of the pathway. Bypass flows (rapid groundwater infiltration through high permeability conduits such as fractures or root-holes) can significantly affect travel time. Although bypass flows were not directly considered in this methodology, they were a key basis for the emphasis on pathway thickness in the vulnerability assessment. For the purposes of the regional scale assessment, bypass flow is assumed to be significant only where the pathway is less than an arbitrary 3 m thick.

The potential for contaminant attenuation is also directly affected by the groundwater flow type and by the clay content of the pathway material. Where groundwater flow is dominantly via fractures, it is assumed that the potential travel time of groundwater to the water table is too short to allow any attenuation to take place. However, where flow is dominantly by intergranular means, there is a greater opportunity for water-rock interaction, filtration and adsorption of certain contaminants (e.g. microbes) within pore spaces, and dilution and dispersion effects on a micro-scale within the pore matrix. If clay is present in soil or superficial deposits, the attenuation potential with regard to groundwater vulnerability is enhanced, as clay has adsorptive qualities that can help reduce concentrations of certain contaminants (e.g. heavy metals) reaching groundwater. Although different clays have difference adsorptive qualities, the majority of clays in Scottish soil and superficial deposits are non-expanding and have relatively low adsorption capacities. Therefore, within the new methodology, which is designed as a screening tool for the Water Framework Directive, it is reasonable to consider only the presence or absence of clay.

The effective pathway - the zone in which contaminant attenuation can occur - varies according to the characteristics of the aquifer forming the receptor. These variations, and the parameters controlling the groundwater vulnerability assessment in each case, are described below and illustrated in Figure 1.

Where the water table lies within a bedrock aquifer with mixed intergranular/fracture flow or fracture flow only, it is assumed that significant attenuation does not occur. In these situations, the pathway consists only of any superficial deposits that overlie the bedrock aquifer. The effective pathway within the vulnerability assessment is therefore shorter than the total pathway length.

Where the water table lies within a superficial aquifer (by definition within the new methodology, this refers to high permeability superficial deposits that are at least partially saturated), the pathway consists only of the unsaturated superficial deposits above the water table. The effective pathway is the same as the total pathway length. Where a superficial aquifer overlies a bedrock aquifer, the uppermost water table in the superficial aquifer is considered to be the receptor.

Where the water table lies within a bedrock aquifer with dominantly intergranular flow, the pathway consists of the unsaturated bedrock above the water table and any overlying superficial deposits. Again, the effective pathway is equal to the total pathway length. The attributes that control the groundwater vulnerability assessment are therefore the effective pathway thickness, and the permeability, clay content and groundwater flow type of the geological material making up the effective pathway. 
Superficial Aquifer

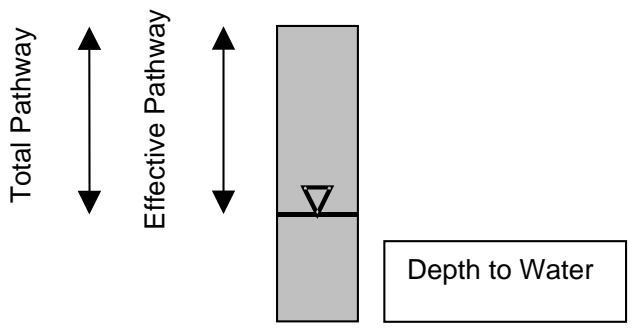

Fractured Bedrock Aquifer: exposed

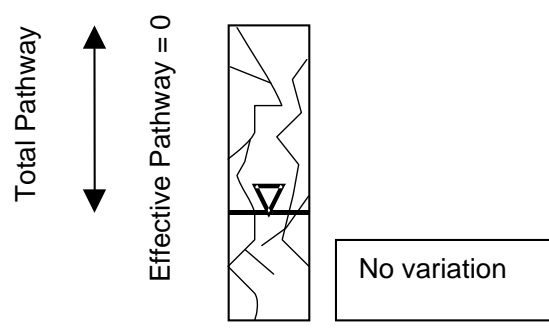

Intergranular Bedrock Aquifer: exposed

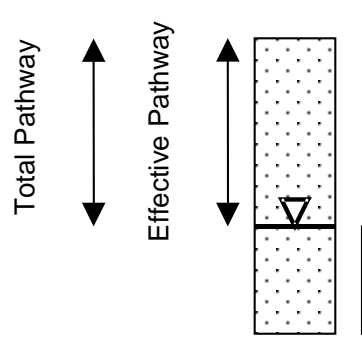

Bedrock Permeability Depth to Water
Fractured Bedrock Aquifer:

soil cover only

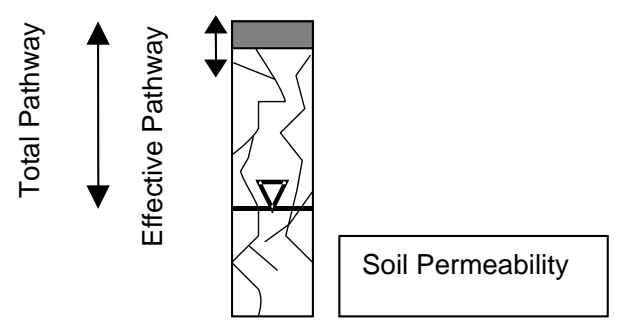

Intergranular Bedrock Aquifer: soil cover only

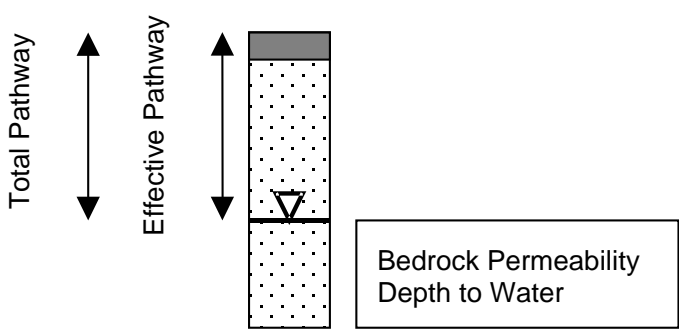

Fractured Bedrock Aquifer:

superficial cover

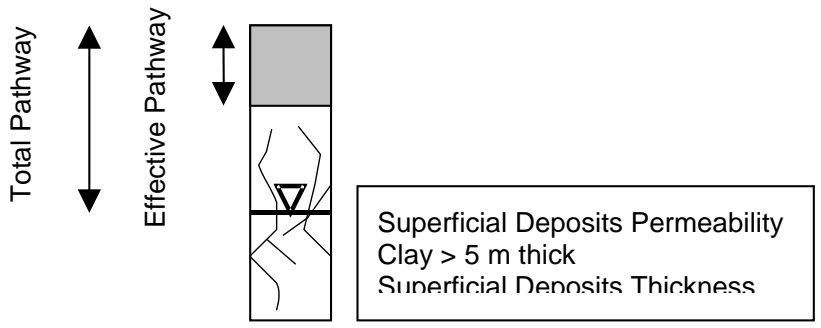

Intergranular Bedrock Aquifer: superficial cover

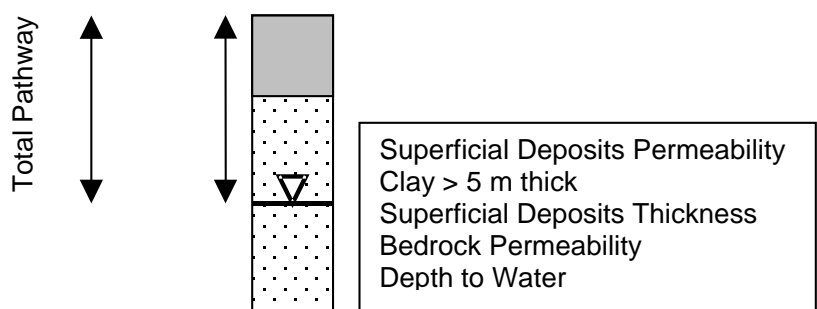

Figure 1

Groundwater vulnerability scenarios showing the pathway attributes that determine vulnerability classification 


\section{Data Availability for Scotland}

The following digital datasets were used in the construction of the map:

DiGMapGB-50, Version 1 (BGS) - This dataset comprises digital geological maps at a working scale of 1:50 000 of both bedrock and superficial geology of Scotland.

DiGMapGB-50 forms the foundation for the vulnerability assessment methodology.

GeoHazard (BGS) - a series of digital datasets including permeability indices derived from pumping tests and lithological descriptions, and a model of superficial deposits thickness.

Single Onshore Borehole Index (SOBI) (BGS) - a digital borehole database containing almost 500000 records in Scotland.

HOST (Hydrology of Soil Types) (MLURI) - digital soils maps at 1:250 000 scale with an assessment of the hydraulic properties of the soil.

Scottish Soils Database (MLURI) - a digital database of approximately 38000 measurements of soil properties including particle size distribution.

\section{Digital Terrain Model (Ordnance Survey)}

River network (Centre for Ecology and Hydrology).

\section{Outline of the new methodology}

The methodology is based on a four step process:

- $\quad$ assessing the type of recharge;

- assessing the type of aquifer forming the receptor and identifying the key pathway characteristics for consideration;

- assessing the characteristics of the pathway;

- assigning a vulnerability classification.

\section{Type of recharge}

Point recharge, for example through karstic swallow holes or mine shafts, will bypass all the pathway elements, allowing no potential for attenuation. The vulnerability of underlying groundwater will therefore always be at a maximum. Diffuse recharge, in contrast, is assumed to interact with the pathway material as it moves towards the water table, and groundwater vulnerability depends on the type of receptor and the pathway characteristics.

The occurrence of point recharge can only be assumed where there are data on features such as karst and mine shafts. In the absence of such national scale data for Scotland, recharge is assumed to be diffuse. However, if groundwater vulnerability assessments are used as part of land use planning or licensing processes in karstic and extensively mined areas, on-site assessments of point recharge features are necessary.

\section{Type of aquifer receptor and identification of key pathway characteristics}

The receptor is the uppermost aquifer in the geological sequence. The type of groundwater flow through this aquifer determines the pathway characteristics that control the vulnerability assessment. Groundwater moves through bedrock either via relatively small, interconnected, 
pore spaces as intergranular flow, or where fractures are present as fracture flow. Groundwater moves through superficial aquifers only as intergranular flow. The aquifers in Scotland were divided into three groups based on groundwater flow type. For each group, the key pathway characteristics that determine groundwater vulnerability are listed.

Superficial aquifers with intergranular flow, which includes all high permeability superficial deposits. In these aquifers, contaminant attenuation in the unsaturated zone can be significant. The key pathway characteristic is the thickness of the unsaturated zone.

Bedrock aquifers with dominantly intergranular flow, which comprises a small number of highly porous sedimentary bedrock formations: Permian sandstones in the Dumfries area, Upper Devonian sandstones in Fife, and Passage Formation sandstones in central Scotland. Fracture flow also occurs in all these aquifers, but does not generally dominate regional groundwater flow. In these aquifers, contaminant attenuation in the unsaturated zone can be significant. The key pathway characteristics are the thickness of the unsaturated zone within the aquifer, and the thickness and permeability of the overlying superficial deposits.

Bedrock aquifers with dominantly fracture flow, which comprise the remainder of the bedrock aquifers in Scotland. Within this group, some rocks show a degree of intergranular flow and storage, but the bulk of groundwater flow (typically more than $80 \%$ of the flow to an abstraction borehole) is through fractures. In these aquifers, significant contamination attenuation in the unsaturated zone is unlikely, due to rapid groundwater flow through fractures. The key pathway characteristics are the thickness and permeability of the overlying superficial deposits.

A map showing aquifer flow type for an illustrative area around Stirling is presented in Figure 2.

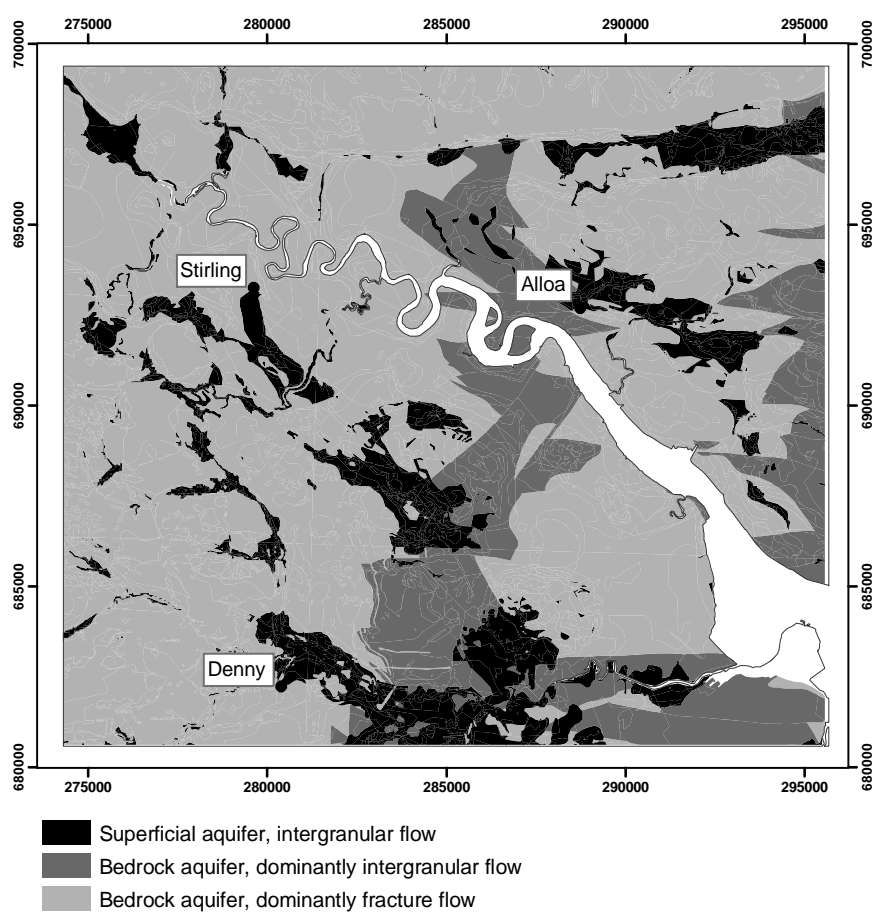

Figure 2

Map showing the distribution of aquifer flow type in the area around Stirling 


\section{Assessing pathway characteristics}

\section{Quaternary deposits permeability}

In the new methodology, Quaternary deposits include both soil and superficial deposits. The latter are defined as those deposits beneath the soil and above bedrock, and are generally at least $1 \mathrm{~m}$ thick. Consequently, where BGS geological maps show no superficial cover, there may be up to $1 \mathrm{~m}$ of soil and superficial deposits present.

\section{Soil permeability}

In the Environment Agency/BGS 1:100 000 scale aquifer vulnerability maps of England and Wales (Palmer and Lewis 1998), soil leaching potential is combined with the characteristics of the underlying geological formations across the maps, although the vulnerability assessment is strongly weighted towards aquifer permeability. In the new methodology, the soil is more integrated within the classification, such that it is considered as a component part of the superficial deposits. Additionally, the characteristics of the soil are allowed to influence groundwater vulnerability directly where bedrock is present within $1 \mathrm{~m}$ of the ground surface (i.e., is overlain by very thin or no superficial deposits apart from the soil itself). Only the permeability of soils is considered, and not its chemical characteristics or leaching potential, as the methodology assumes only conservative, non-specific contaminants are released.

Where superficial deposits are thicker than $1 \mathrm{~m}$, it is assumed that the influence of soil permeability on groundwater vulnerability is masked by the stronger influence of the superficial deposits.

Soils were classified according to the HOST classification (Boorman et al. 1995), based on their presence and their permeability, as either: moderate and high permeability; low permeability; or absent (i.e., bare rock is exposed or soil is generally less than $0.3 \mathrm{~m}$ thick).

\section{Superficial deposits permeability}

Superficial deposits were divided into three classes: high, moderate or low permeability. Lower permeability deposits will result in a greater capacity for attenuation.

Most superficial deposits were classified by reference to BGS superficial deposits maps and lithological descriptions. High permeability deposits are those dominated by sands and gravels, including river alluvium and glaciofluvial sheet deposits. Moderate permeability deposits are those where there is a high proportion of fine-grained silty material as well as sand, such as in many raised marine deposits. Low permeability deposits are those dominated by clays, including peat and many lacustrine deposits.

The permeability of glacial till and moraine is more complex to classify, as they vary from low permeability clays to high permeability gravely deposits. The lithological variation in glacial till across Scotland has not yet been systematically mapped. Instead, till and moraine deposits were subdivided according to the permeability of the soil parent material as described in the Scottish Soils Database (MLURI), and their spatial distribution assigned using the Hydrology of Soil Types (HOST) spatial dataset (Boorman et al 1995, Lilly et al 1998).

Where the HOST classification showed the absence of a perched water table and/or low clay content, the till and moraine deposits were judged to have high permeability. In general, these highly permeable tills are found across the Highlands and Islands, Aberdeenshire and parts of southern Scotland. 
The remaining till and moraine deposits, generally found in the Midland Valley and the Borders, were subdivided on the basis of the clay content of the soil parent material, which is inherited from the lithology of the parent rock. Descriptions of the component parent rock were used to assign the remaining till and moraine deposits to one of two groups: those with a significant component of shales and/or mudstones, and those where these rocks are absent. For each soil profile within the Scottish Soils Database (Langan et al 1996) that fell into either of these two groups, information on the measured particle size distribution for the relatively unaltered basal soil horizon was extracted. An Analysis of Variance showed that there was a significant difference between the two mean clay contents $(\mathrm{p}<0.001)$, indicating that the clay content of the soils derived from rocks with a significant proportion of shales and mudstones was significantly greater than the clay content of soils derived dominantly from sandstones and hard rocks. Assuming a direct relationship between permeability and the clay content of the unconsolidated superficial deposits, the till and moraine deposits with the smaller clay content were classed as having moderate permeability, and those with the greater clay content as having low permeability. The spatial distribution of these two groups was determined by a simple reclassification of the 1:250 000 scale HOST and soil maps for Scotland.

Maps showing soil and superficial deposit permeability classes for the same area around Stirling as in Figure 2 are presented in Figures 3 and 4.

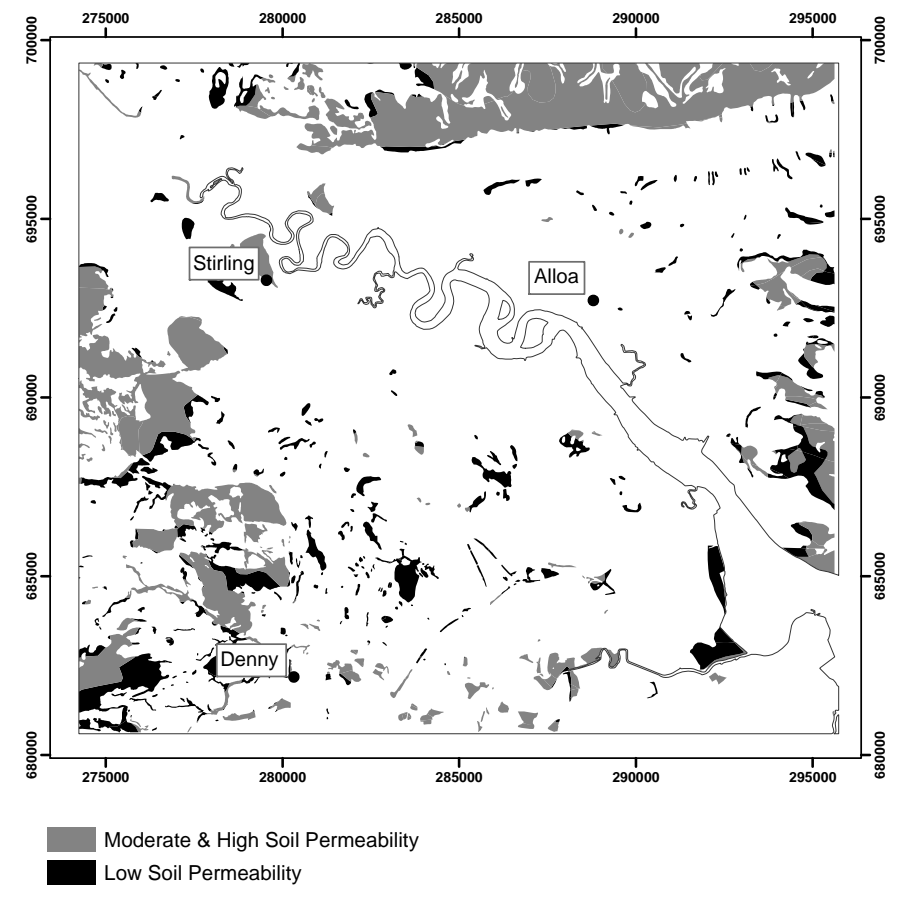

Figure 3

Map showing the distribution of soil permeability in the area around Stirling 


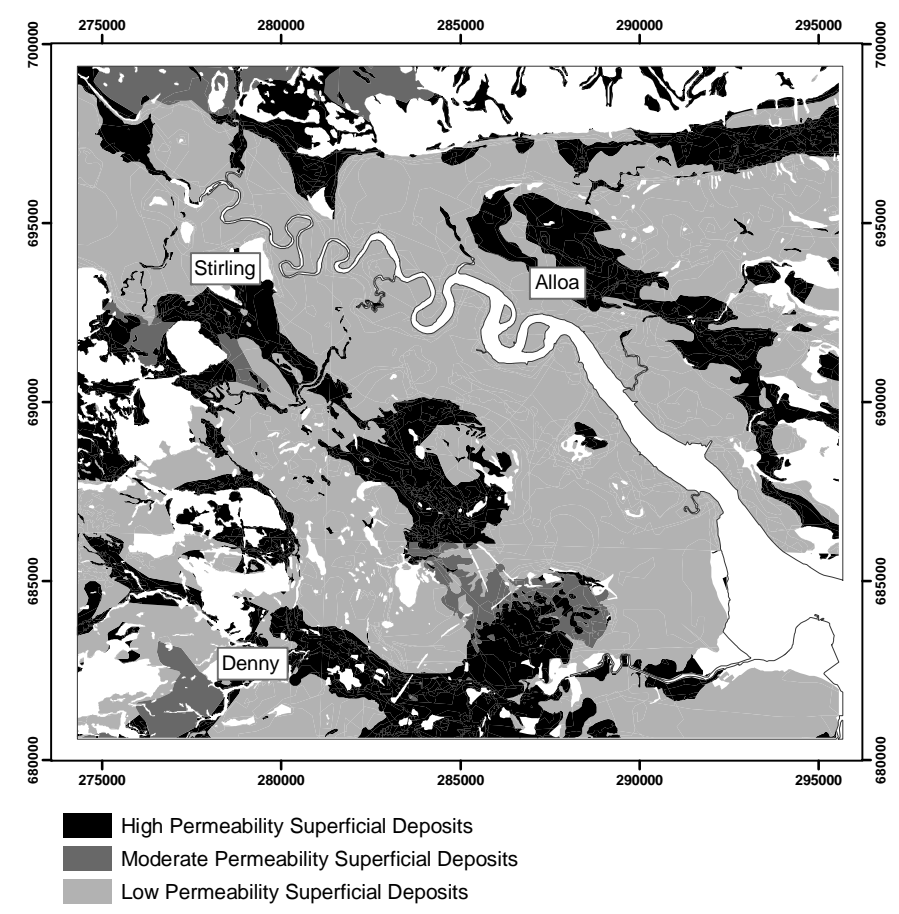

Figure 4 Map showing the distribution of superficial deposits permeability in the area around Stirling

\section{Superficial deposits thickness}

Where the uppermost water table is within a superficial aquifer, only the depth to the water table is relevant to the vulnerablity assessment, not the total thickness of the superficial deposit. However, where the uppermost water table is within a bedrock aquifer beneath superficial cover, the thickness of that cover is considered an important part of the pathway within the vulnerability methodology. Superficial deposits provide a pathway in which attenuation of contaminants can occur and, in general, the thicker the deposits, the more attenuation is possible.

A digital map of the thickness of superficial deposits in Scotland was available prior to the development of the groundwater vulnerability methodology. This was developed using information on depth to rockhead from available borehole records to contour the thickness of superficial deposits. Four thickness classes were distinguished for the purposes of the vulnerability methodology: 1 to $3 \mathrm{~m}$; 3 to $10 \mathrm{~m} ; 10$ to $30 \mathrm{~m}$; and greater than $30 \mathrm{~m}$.

This method works well where there is sufficient borehole information, but for much of Scotland, including most of the Highlands and Islands, there are few borehole records, and the existing map was of limited use. The superficial deposits thickness map was modified based on the current knowledge of Quaternary geology in Scotland. In the absence of borehole data, all mapped river alluvium and glaciofluvial sand and gravels in valleys, and all raised beach and blown sand deposits along the coast, are assumed to be between 3 and $10 \mathrm{~m}$ thick. All till and moraine deposits on valley sides and high ground are assumed to be between 1 and $3 \mathrm{~m}$ thick. Although the improved map is still based on estimates across much of Scotland, it is based on field experience and in most cases is likely to be broadly correct. It currently provides the most realistic superficial deposits thickness model available for Scotland. 
A map showing superficial deposits thickness for the same area around Stirling is presented in Figure 5.

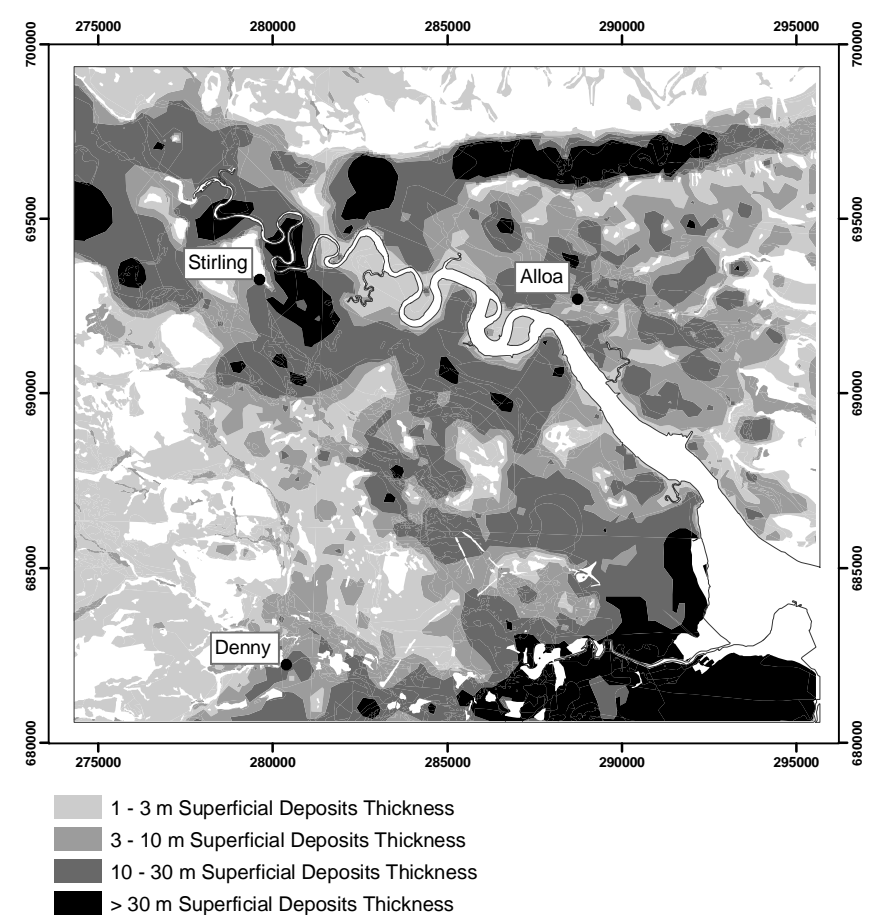

Figure 5

Map showing the distribution of the thickness of superficial deposits in the area around Stirling

\section{Thick clays}

The permeability classifications were developed further by identifying zones where a significant thickness (greater than $5 \mathrm{~m}$ ) of clay is present within the superficial deposit sequence, based on available borehole lithological data in BGS databases. Although there are large areas of Scotland where borehole data are scarce, the identified zones are thought to encompass the main areas in which thick clays occur in Scotland. Because superficial deposits can be extremely heterogeneous, thick clays may occur at depth even where high permeability deposits are mapped at the surface. Where the uppermost water table is in a superficial aquifer, the presence of clays beneath this does not affect the vulnerability assessment, as the clays do not form part of the pathway. However, where underlying bedrock aquifer contains the uppermost water table, the presence of $5 \mathrm{~m}$ or more of clay within the superficial deposit sequence affects the overall pathway permeability.

A map showing the presence of clays greater than $5 \mathrm{~m}$ thick in the area around Stirling is presented in Figure 6. 


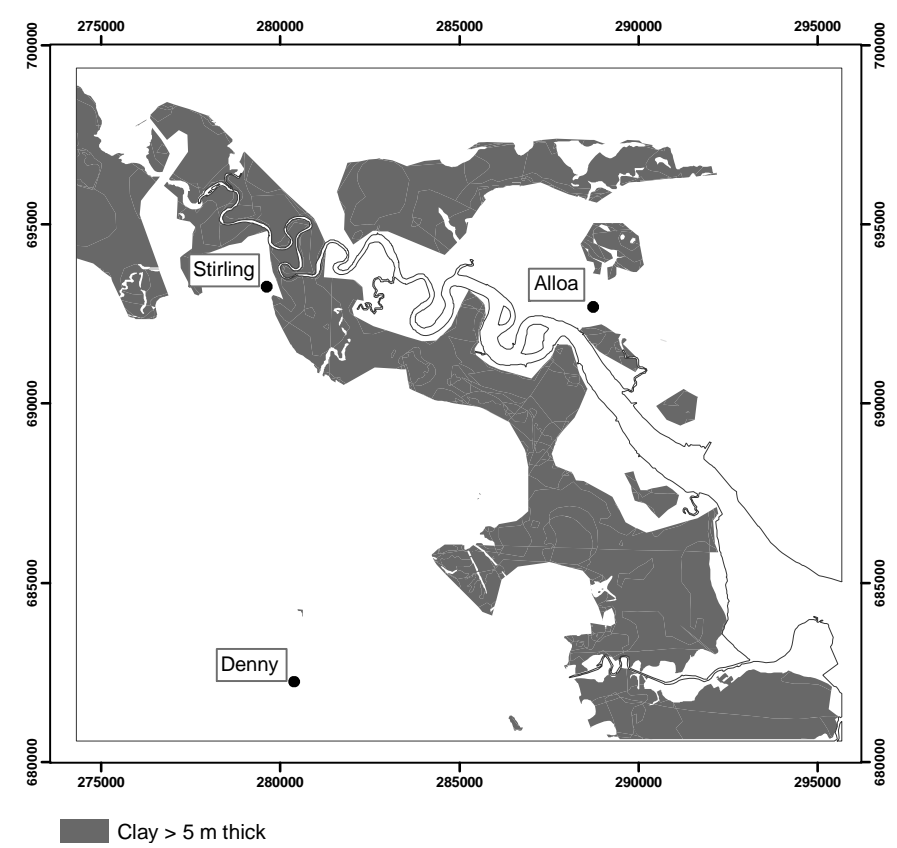

Figure 6 around Stirling

Map showing the distribution of clays over $5 \mathrm{~m}$ thick in the area

\section{Depth to water}

Information on the depth to groundwater is not available for most of Scotland, in particular for superficial aquifers. A method for estimating the base groundwater level in superficial deposits in valleys was developed using a digital terrain model (DTM) and a map of the SEPA national river network. This is based on the concept that the depth to the water table is greater beneath relatively high ground than beneath valley floors or close to the coast. The method assumes that the river level (or sea level at the coast) equates to the water table surface. The maximum depth to water table, for a distance of up to $3 \mathrm{~km}$ laterally from major rivers and the coast, was estimated by calculating the difference in elevation from the ground surface on the valley side to the river level in the valley bottom. The model was improved by including data on the presence of certain HOST soil classes that indicate the presence of a shallow water table (notionally within $2 \mathrm{~m}$ of the ground surface) in interfluvial areas. The resultant distribution of the depth to water map was integrated only with those areas where high permeability superficial aquifers are present.

Four classes of depth to water are distinguished: 0 to $3 \mathrm{~m} ; 3-10 \mathrm{~m} ; 10-30 \mathrm{~m}$; and greater than $30 \mathrm{~m}$.

The depth to the water table in bedrock is relevant only in those aquifers with dominantly intergranular flow. These include some of the most heavily used aquifers in Scotland, for which there is normally at least some information on depth to water. For bedrock aquifers, therefore, depth to water information was drawn up manually, based on available water level measurements. Four classes are again distinguished: 0 to $3 \mathrm{~m} ; 3-10 \mathrm{~m} ; 10-30 \mathrm{~m}$; and greater than $30 \mathrm{~m}$.

A map showing depth to the water table in superficial deposits aquifers for the same area around Stirling is presented in Figure 7. A map showing depth to the water table in intergranular bedrock aquifers for the same area is presented in Figure 8. 


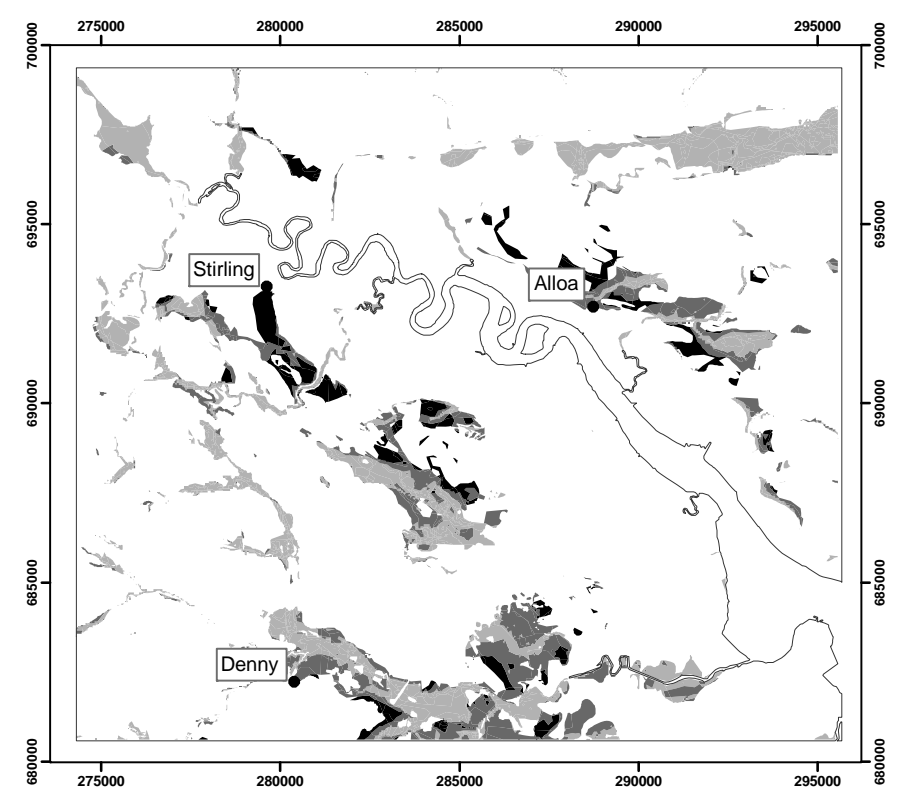

0 - $3 \mathrm{~m}$ to Water Table

3- $10 \mathrm{~m}$ to Water Table

10 - $30 \mathrm{~m}$ to Water Table

Figure $7 \quad$ Map showing the distribution of the depth to water table in superficial deposits aquifers in the area around Stirling

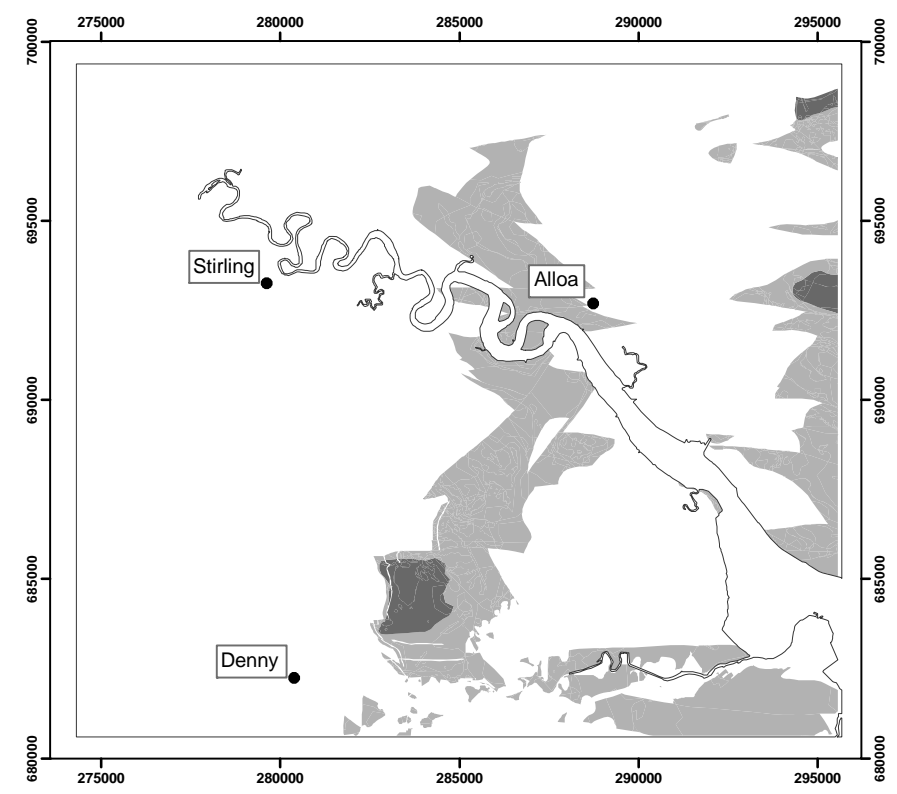

0 - $3 \mathrm{~m}$ to Water Table

$3-10 \mathrm{~m}$ to Water Table

Figure 8 Map showing the distribution of the depth to water table in bedrock aquifers dominated by intergranular flow in the area around Stirling

\section{Bedrock permeability}

In bedrock aquifers where groundwater flow is dominantly intergranular, the permeability of the aquifer will affect the characteristics of the pathway used to assess vulnerability. Lower 
permeability rocks will result in a greater capacity for attenuation. Aquifers were divided into three classes: high, moderate or low permeability, by reference to lithological descriptions within BGS databases. In Scotland, all the bedrock aquifers with dominantly intergranular flow in Scotland are classed as highly permeable.

\section{Assigning a vulnerability classification}

Five classes of groundwater vulnerability have been distinguished, based on those suggested by Foster (1998). The classes denote general and relative degrees of vulnerability. In the areas with highest vulnerability, groundwater is vulnerable to most types of contaminant, and contamination is rapid. In the areas with lowest vulnerability, groundwater is only vulnerable to conservative contaminants (such as chloride and nitrates) where these have been persistently introduced over a long timescale. Definitions of the five vulnerability classes in terms of the frequency of contamination activities and the travel time of contaminants are given in Table 1.

There are seven possible combinations of aquifer type, soil and superficial cover within the new methodology. These combinations, or vulnerability scenarios, were illustrated in Figure 1, showing the effective pathway between the ground surface and the water table in each case. The attributes of the pathway (the classes into which each of the variables above is divided) control the vulnerability classification within each scenario, and are summarised in Figure 1 and Table 2.

Within each of the scenarios, the vulnerability classification is determined through a series of matrices combining the key pathway attributes, or classes. For example, where a superficial aquifer is present at the ground surface, the vulnerability classification depends only on the depth to water table (Table 2), and a single matrix is used to assign vulnerability depending on whether the depth to water table is 0 to $3 \mathrm{~m}, 3$ to $10 \mathrm{~m}, 10$ to $30 \mathrm{~m}$, or greater than $30 \mathrm{~m}$. In another example, where a fractured bedrock aquifer is present, the vulnerability classification depends on whether the bedrock is exposed at the surface or has a cover of soil or superficial deposits (Table 2). Different matrices are used in each case: for example, where there is a soil cover but no superficial deposits, a matrix assigns vulnerability depending on whether soil permeability is moderate and high, or low.

The following general rules were used to ensure the matrices were developed according to consistent, scientific principles:

- Groundwater is most vulnerable in areas where point recharge can bypass superficial deposits, and where fractured unsaturated bedrock allows rapid groundwater flow to the water table.

- All bedrock is liable to fracturing to some degree. Some protection from thick and/or low permeability superficial deposits is therefore required to significantly reduce vulnerability, even where bedrock has a significant intergranular porosity.

- Superficial deposits can also be fractured and their thickness and properties are often variable over short distances. As such, mapped thicknesses of greater than $3 \mathrm{~m}$ are required to significantly reduce vulnerability.

- The capacity of the soil to attenuate contaminants and affect groundwater vulnerability is only assumed to be significant where superficial deposits are absent or are less than 1 m thick.

An extract of the new groundwater vulnerability map for the same area around Stirling as shown in the previous maps is presented in Figure 9. 
Table 1 Definition of vulnerability classes with regard to the frequency of contamination activity and the travel time of contaminants through the pathway (adapted from Foster 1998)

\begin{tabular}{|c|c|c|c|}
\hline $\begin{array}{l}\text { VULNERABILITY } \\
\text { CLASS }\end{array}$ & DESCRIPTION & $\begin{array}{c}\text { RELATIONSHIP TO } \\
\text { THE FREQUENCY OF } \\
\text { CONTAMINATION } \\
\text { ACTIVITY } \\
\end{array}$ & $\begin{array}{l}\text { TRAVEL } \\
\text { TIME }\end{array}$ \\
\hline 5 & $\begin{array}{l}\text { Vulnerable to most water } \\
\text { contaminants with rapid } \\
\text { impact in many cases. }\end{array}$ & \multirow{5}{*}{$\begin{array}{l}\begin{array}{l}\text { Vulnerable to individual } \\
\text { events }\end{array} \\
\qquad \\
\text { Vulnerable only to } \\
\text { persistent activity }\end{array}$} & \\
\hline 4 & $\begin{array}{l}\text { Vulnerable to those } \\
\text { contaminants not readily } \\
\text { adsorbed or transformed. }\end{array}$ & & \\
\hline 3 & $\begin{array}{l}\text { Vulnerable to some } \\
\text { contaminants, but many are } \\
\text { significantly attenuated. }\end{array}$ & & \\
\hline 2 & $\begin{array}{l}\text { Vulnerable to some } \\
\text { contaminants, but only when } \\
\text { continuously introduced. }\end{array}$ & & \\
\hline 1 & $\begin{array}{l}\text { Only vulnerable to } \\
\text { conservative contaminants in } \\
\text { the long-term when } \\
\text { continuously and widely } \\
\text { introduced. }\end{array}$ & & Very slow \\
\hline
\end{tabular}


Table 2

Pathway attributes that determine vulnerability classification for each vulnerability scenario

\begin{tabular}{|c|c|c|}
\hline \multicolumn{3}{|c|}{ SUPERFICIAL DEPOSITS } \\
\hline $\begin{array}{l}\text { EXPOSED } \\
\text { BEDROCK }\end{array}$ & SOIL COVER ONLY & SUPERFICIAL COVER \\
\hline
\end{tabular}

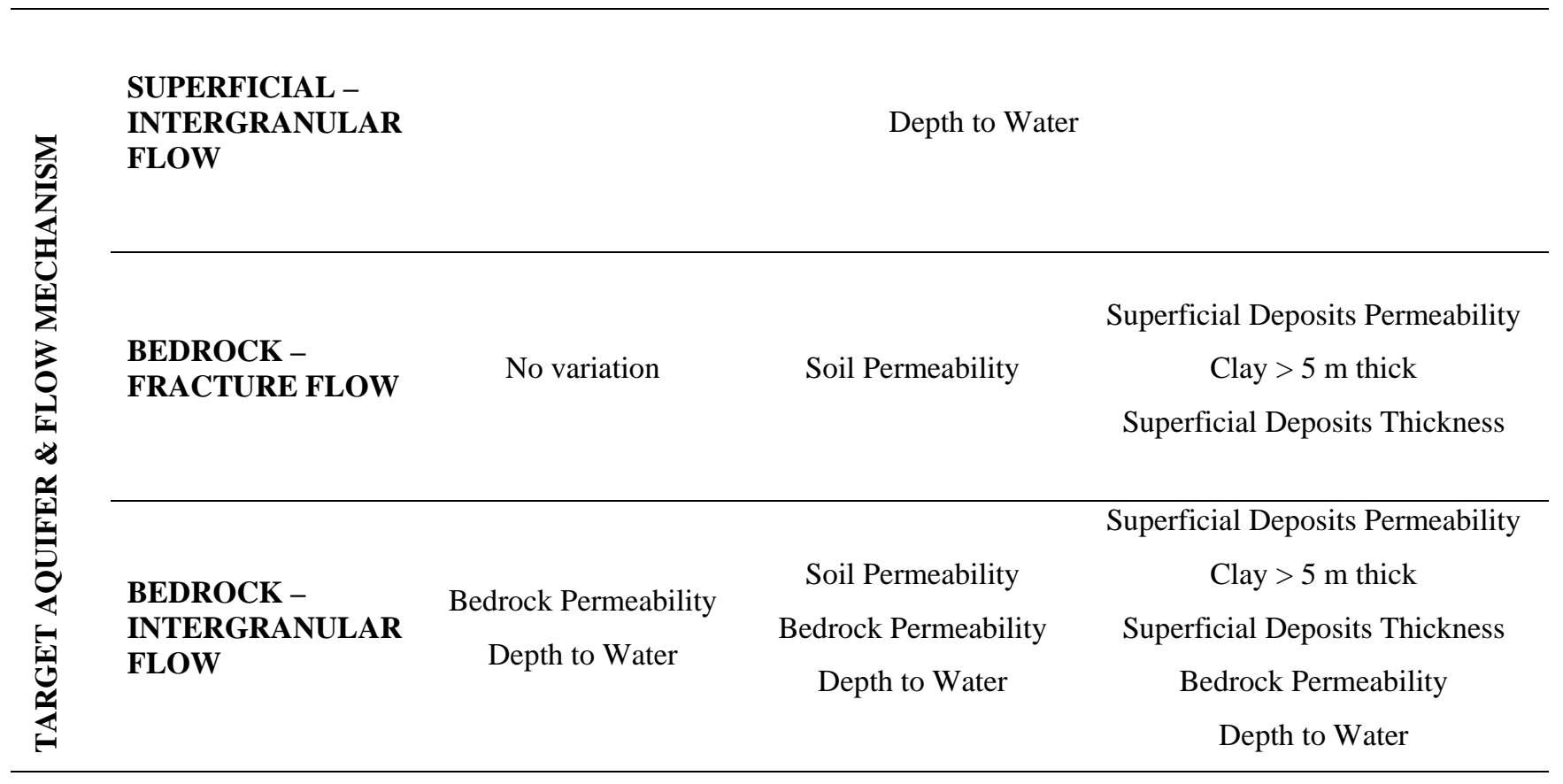



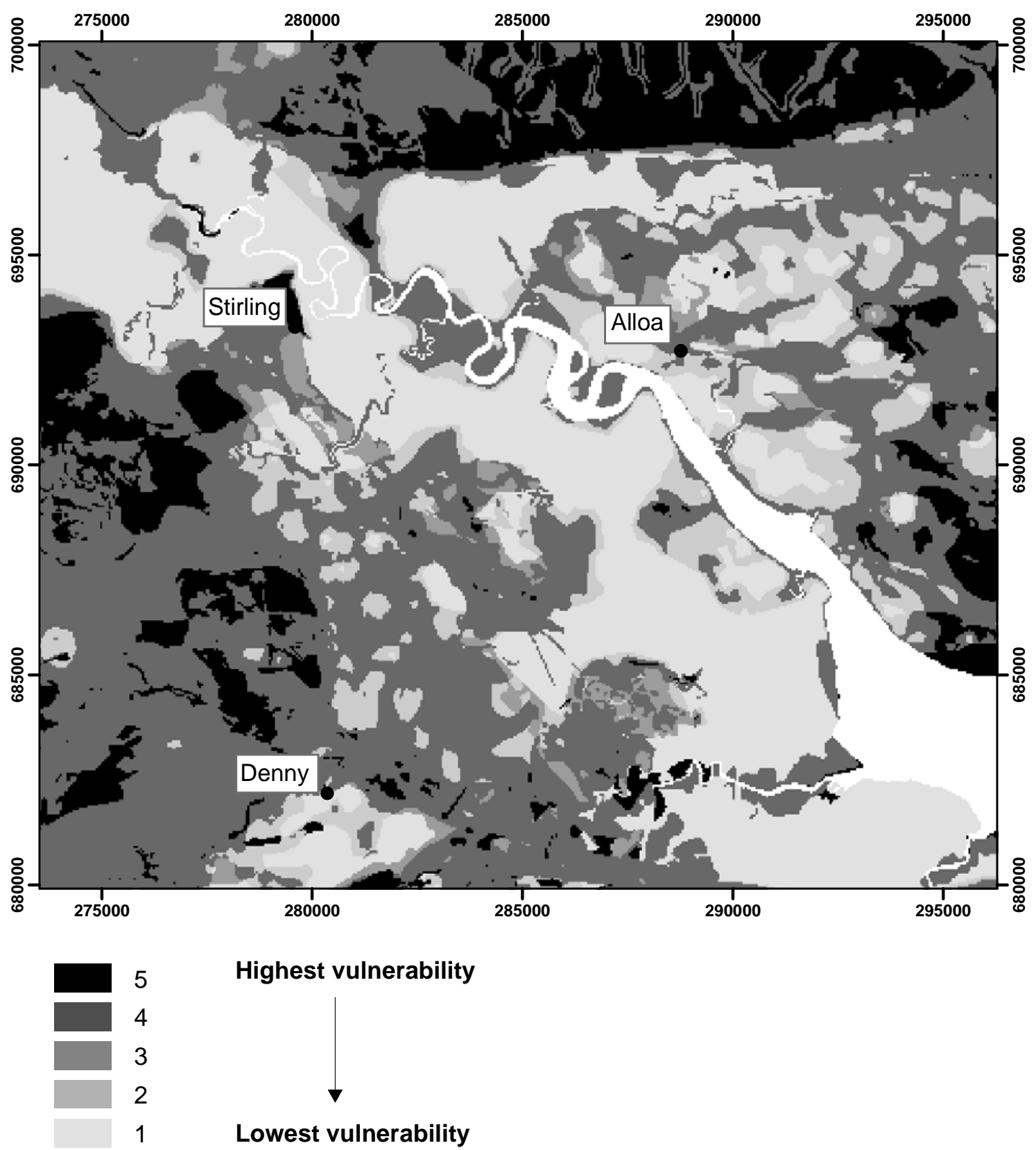

Figure 9

Map of groundwater vulnerability in the area around Stirling 


\section{Application of the Groundwater Vulnerability Map}

The new groundwater vulnerability map will help underpin SEPA's approach to the implementation of the groundwater protection aspects of the Water Framework Directive. As a stand-alone product, it provides an overview of groundwater vulnerability across Scotland at a suitable scale for use in groundwater body characterisation.

Where there is information on known point recharge features, the methodology can be adapted to take specific account of potential point source pollution. For example, areas within a set distance from a point recharge feature, such as a swallow hole in karstic limestone, could be classified as having very high vulnerability.

A further application is the development of an integrated GIS-based suite of maps that would include groundwater vulnerability, aquifer productivity, land use hazards and key groundwater and groundwater-dependent receptors. If developed in conjunction with appropriate guidance documents, such a suite of maps would be a powerful tool to help regulators make objective, risk-based prioritisation decisions on the scope of any ground investigations.

The GIS-based methodology is also applicable to other areas where digital data are available.

\section{Conclusions}

The new GIS-based groundwater vulnerability map illustrates the relative risk to groundwater from contamination at a regional scale across the whole of Scotland, by revealing the likelihood of a non-specific contaminant moving vertically downward and reaching the uppermost aquifer after introduction at the ground surface.

The methodology behind the map is based on a standard hazard-pathway-receptor model of groundwater vulnerability. It considers the intrinsic geological and hydraulic properties of the pathway between the ground surface and the water table in the uppermost aquifer.

Based on this model, the map shows that groundwater is most vulnerable where fractured aquifers with a shallow water table are overlain by a thin cover of superficial deposits and/or soil. The areas where groundwater is least vulnerable are those where aquifers are protected by a thick unsaturated zone (deep water table) and a thick cover of low permeability clayey superficial deposits.

A key difference between this and previous groundwater vulnerability maps developed for Scotland and the rest of the UK is that the new methodology focuses on the Water Framework Directive requirement to protect groundwater in all groundwater bodies, regardless of resource potential.

A further difference in the new method is that soils data have been integrated into the classification of superficial deposit permeability, rather than simply overlain. This has produced a more rigorous assessment of both the potential for rapid downward movement of infiltrating water and contaminants, and the potential for contaminant attenuation. By contrast, in past classifications the soil properties often outweighed the protection afforded by thick, clayey superficial deposits.

The new map allows national consistency in groundwater vulnerability assessments. It is an integral part of SEPA's approach to the implementation of the groundwater protection aspects of the Water Framework Directive. 


\section{Acknowledgements}

We acknowledge the support of the following: SNIFFER; SEPA; Hugh Barron, Peter McConvey and Nick Robins, BGS; Rob Ward and Steve Fletcher, Environment Agency; and Donal Daly, Geological Survey of Ireland. The paper is published by permission of the Director, British Geological Survey (NERC).

\section{References}

Ball D F, MacDonald A M AND Lilly A. 2005. Agriculture and diffuse pollution: groundwater nitrate vulnerable zones in Scotland. This volume.

BRItish GeOlogical Survey. 1988. Hydrogeological map of Scotland Scale 1:625 000. BGS, Keyworth.

BOORMAN D B, Hollis J M AND LiLly A. 1995. Hydrology of soil types: a hydrologically-based classification of the soils of the United Kingdom. Institute of Hydrology Report No. 126. Institute of Hydrology, Wallingford.

DELG/EPA/GSI. 1999. Groundwater Protection Schemes. Department of the Environment and Local Government, Environmental Protection Agency and Geological Survey of Ireland.

FOSTER S S D. 1998. Groundwater recharge and pollution vulnerability of British aquifers: a critical review. In Groundwater Pollution, Aquifer Recharge and Vulnerability. RoBINS N S (editor). Geological Society, London, Special Publications. 130, 7-22.

LANGAN S J, PATERSON E AND TAYLOR A G. 1996. The Scottish Soil Resource: Its current status and future priorities for its management. In Soil, Sustainability and the Natural Heritage. TAYLOR A G AND USHER M (editors). HMSO, Edinburgh. 69-92.

LiLly A, BOORMAN D B AND HolLis J M. 1998. The development of a hydrological classification of UK soils and the inherent scale changes. Nutrient Cycling in Agroecosystems, 50, 299 - 302.

MacDonald A M, RoBins N S, BALl D F AND Ó DOCHARTAIGH B É. 2005. An overview of aquifer productivity in Scotland. This volume.

PALMER R C AND LEWIS MA. 1998. Assessment of groundwater vulnerability in England and Wales. In Groundwater Pollution, Aquifer Recharge and Vulnerability. RoBINS N S (editor). Geological Society, London, Special Publications.130, 191-198.

Robins N S, MACDonald A M AND Allen D J. 2004. The vulnerability paradox for hard fractured Lower Palaeozoic and Precambrian rocks. Conference Paper, Ustron, Poland, 16-19 June 2004. 